\title{
Archaeological and Historical Evidence for an 18th-Century "Blip" in the Distribution of the Northern Fur Seal at Kodiak Island, Alaska
}

\author{
DONALD W. CLARK ${ }^{1}$
}

\author{
(Received 4 September 1984; accepted in revised form 17 April 1985)
}

\begin{abstract}
Recovery of fur seal Callorhinus ursinus remains from archaeological sites on Kodiak Island, Alaska, shows a low harvest prior to late prehistoric and early historic time. Then there is a pronounced increase in the frequency of fur seal bones in refuse layers. Russian records do not show any significant take of fur seals from Kodiak, but by the end of the 18th century and the beginning of the next century there are reports that this animal, formerly abundant in the area, had become rare. This may indicate that conditions had reverted to their earlier prehistoric state.

Key words: Alaska, fur seals, archaeology, osteo-archaeology

RÉSUMÉ. Le volume des restes de l'otarie à fourrure Callorhinus ursinus qu'on a retrouvés dans les sites archéologiques de l'île Kodiak en Alaska montre que cette espèce était pue capturée avant la fin de la préhistorie et le début de l'historie. On constate alors une augmentation marquée de la fréquence des ossements de l'otarie à fourrure. Les documents russes ne témoignent pas de prises importantes d'otaries à furrure dans l'île Kodiak, mais à la fin du XVIII siècle et au début du XIX ${ }^{e}$ on signale à différentes reprises que cet animal, qui aurait été abondant autrefois, est devenu rare. Cela indique peut-être que les conditions étaient redevenues ce qu'elles étaient à l'époque préhistorique.

Mots clés: Alaska, otaries à fourrure, archéologie, ostéo-archéologie
\end{abstract}

\section{INTRODUCTION}

People often envision hundreds of thousands or millions of fur seals congregating off the coast of California and then streaming northward, well out to sea, for a rendezvous on the Pribilof Islands and a few months of cramped harem life. That is only part of the life history of the fur seal. Fur seals frequent both inshore and offshore areas and many can be found during the winter months in the protected bays of southern Alaska and British Columbia (Banfield, 1974:360; Kenyon and Wilke, 1953; Pike and MacAskie, 1969), but they have not been recorded as common in the bays and nearshore waters of Kodiak Island on the west side of the Gulf of Alaska (Fig. 1).

A highly effective mode of long-term biological sampling is the analysis of kitchen middens or refuse deposits left at ancient habitation sites. A number of assumptions must be made in interpreting the results, but used prudently, faunal analysis may provide insight into differences in the distribution of a species.

An abundance of fur seal bones in certain late-prehistoric and early-historic Koniag Eskimo archaeological sites accordingly is interpreted to indicate that at one time fur seal had become numerous close to the coast along the southeastern side of Kodiak Island.

\section{ARCHAEOLOGICAL EVIDENCE}

Faunal refuse collections were obtained from five Kodiak Island sites by the University of Wisconsin Aleut-Konyag Project in the 1960s (Tables 1 and 2; Clark, 1970, 1974). Fur seal remains are seen to be several times more abundant in each of three late sites than in two earlier first millennium A.D. sites.

Regional North Pacific comparisons were made between fur seal and harbor (hair) seal, the two most common mammals in the late sites on Kodiak (Clark, n.d.). From the north end of Kodiak Island eastward fur seal bones are rare. Farther to the south in British Columbia and Washington fur seal remains again are abundant. West of Kodiak fur seals also were one of the most common mammals harvested. The western occurrences in the Aleutian Islands are readily explained by the proximity of sites to the passes taken by the seals to reach the Pribilof Islands. Kodiak Island is situated far from these passes. Nevertheless, the presence of a seal fishery there, coupled with the apparent absence of one farther east around the Gulf of Alaska during late prehistoric times, provides a clue that a peculiarity of the seal migration pattern may be involved. However, on Kodiak there also is a temporal factor, expressed in very late abundance, whereas in Aleutian sites (Lippold, 1966) and in Washington (Gustafson, 1968) fur seal remains are more or less equally abundant over several millennia.

The intensity of early fur seal exploitation on Kodiak is documented at the Three Saints and Crag Point sites, which are coeval. On the basis of circumstantial evidence these sites appear to be winter (October-April) settlements (Clark, 1970). They are not located near salmon streams that would have provided a basis and reason for summer occupation. Differences in the ratio of fur seal to harbor seal elements, 0.01 and 0.12 at the two sites respectively, therefore may indicate easier access to fur seals from one site than from the other. These sites were abandoned by approximately 1000 A.D., after they had been occupied throughout most of the first millennium, whereas occupation of the excavated portions of the Kiavak and Rolling Bay sites only began about 1500 or 1600 A.D. This pair of sites was visited by Lisianski (1814) at the beginning of spring 1805 , when they were still viable winter villages. Whether or not there were any summer inhabitants has not been established, but most residents probably would have departed for salmon fishing elsewhere. Presently, there is no indication of the level of fur seal utilization for the approximate period of 1000-1500 A.D. After that time the ratios 3.2 and 0.54 fur seal to 1 harbor seal apply to the remaining 300 years of prehistory and early contact history on the southeastern side of Kodiak Island at the Rolling Bay and Kiavak sites respectively (Table 2). Additional data (in the tables) come from the Artel site, located adjacent to the Three Saints site, which is not discussed here because of uncertainty regarding its exact late age and season of occupation.

A more precise periodization is attainable through subdividing the site deposits. This is indicated in Table 2 and is explicated elsewhere (Clark, n.d.). Beginning with the Three

\footnotetext{
${ }^{1}$ Archaeological Survey of Canada, National Museum of Man, Ottawa, Ontario, Canada K1A 0M8

(C) The Arctic Institute of North America
} 


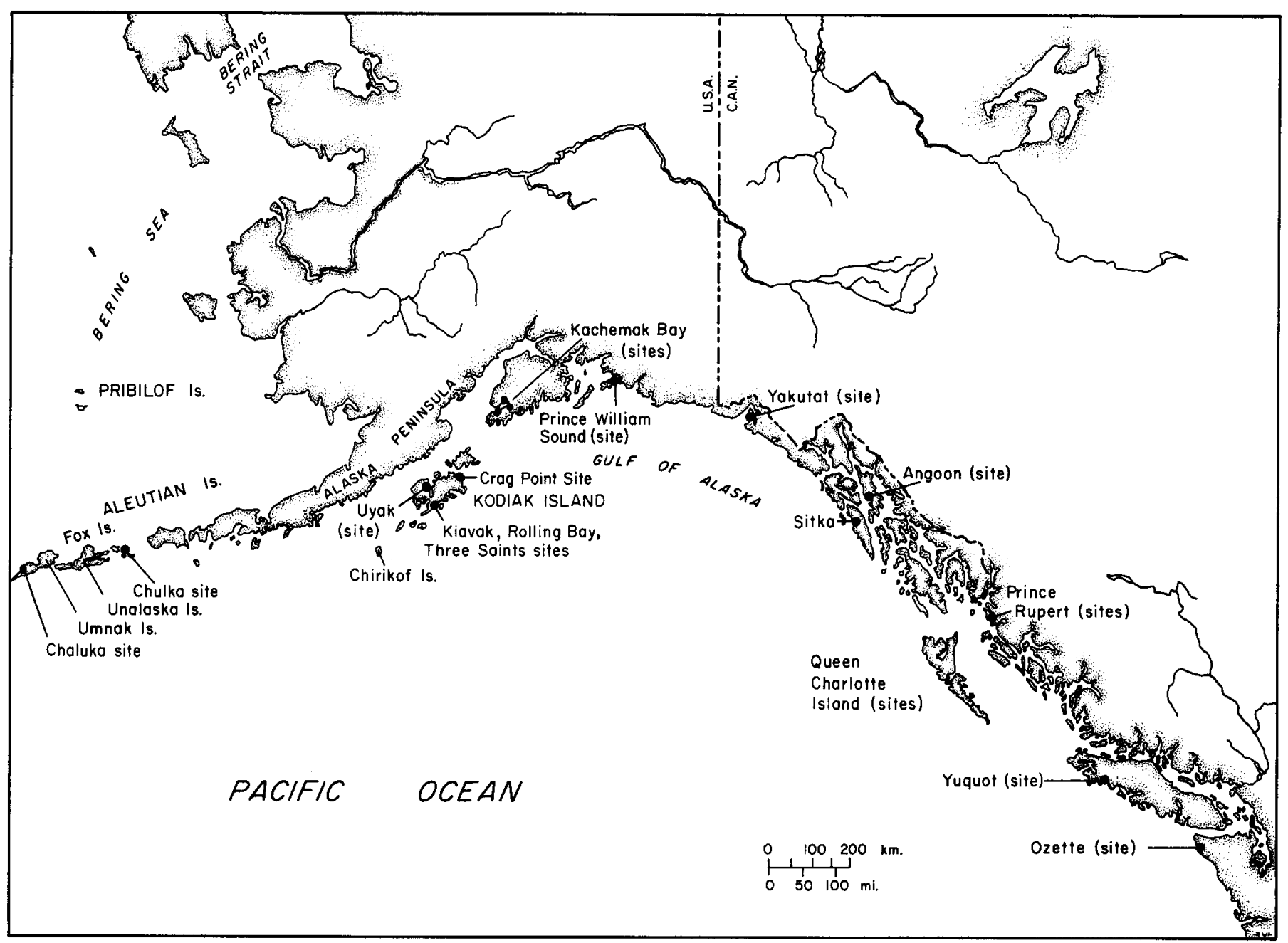

FIG. 1. Location of archaeological sites on Kodiak Island and other sites that have yielded information relevant to prehistoric exploitation of fur seals.

TABLE 1. Kodiak faunal analysis for selected elements, sea mammals

\begin{tabular}{|c|c|c|c|c|c|c|}
\hline \multirow[b]{2}{*}{ Species } & & \multicolumn{2}{|c|}{$\begin{array}{l}\text { Older sites } \\
\text { Kachemak tradition }\end{array}$} & \multicolumn{3}{|c|}{$\begin{array}{l}\text { Younger sites } \\
\text { Koniag }\end{array}$} \\
\hline & & $\begin{array}{l}\text { Crag } \\
\text { Point } \\
\end{array}$ & $\begin{array}{l}\text { Three } \\
\text { Saints }\end{array}$ & Artel & Kiavak* & $\begin{array}{l}\text { Rolling } \\
\text { Bay II }\end{array}$ \\
\hline $\begin{array}{l}\text { Phoca vitulina } \\
\text { Harbor seal } \\
\text { Callorhinus ursinus } \\
\text { Fur seal } \\
\text { Eumetopias jubata } \\
\text { Sea lion } \\
\text { Enhydra lutris } \\
\text { Sea otter } \\
\text { Porpoise } \\
\end{array}$ & $\begin{array}{l}\text { No. } \\
\% \\
\text { No. } \\
\% \\
\text { No. } \\
\% \\
\text { No. } \\
\% \\
\text { No. } \\
\% \\
\end{array}$ & $\begin{array}{l}175 \\
83.7 \\
2 \\
1.0 \\
5 \\
2.4 \\
4 \\
1.9 \\
23 \\
11.0 \\
\end{array}$ & $\begin{array}{l}167 \\
73.6 \\
20 \\
8.8 \\
4 \\
1.8 \\
1 \\
0.4 \\
35 \\
15.4\end{array}$ & $\begin{array}{l}172 \\
61.0 \\
98 \\
34.8 \\
0 \\
0 \\
2 \\
0.7 \\
10 \\
3.5\end{array}$ & $\begin{array}{l}92 \\
52.0 \\
50 \\
28.2 \\
4 \\
2.3 \\
1 \\
\quad 0.6 \\
30 \\
16.9\end{array}$ & $\begin{array}{c}58 \\
19.6 \\
184 \\
62.0 \\
6 \\
2.0 \\
0 \\
0 \\
49 \\
16.5\end{array}$ \\
\hline \multirow[t]{2}{*}{ Total } & No. & 209 & 227 & 282 & 177 & 297 \\
\hline & & $\begin{array}{l}\text { Northern } \\
\text { Kodiak }\end{array}$ & \multicolumn{4}{|c|}{ Southern Kodiak \& Sitkalidak Island } \\
\hline
\end{tabular}

* Includes a few specimens not from the main trench, which is the basis for the ratios discussed in the text. 
TABLE 2. Ratio of fur seal bones to harbor seal bones in archaeological sites on Kodiak Island

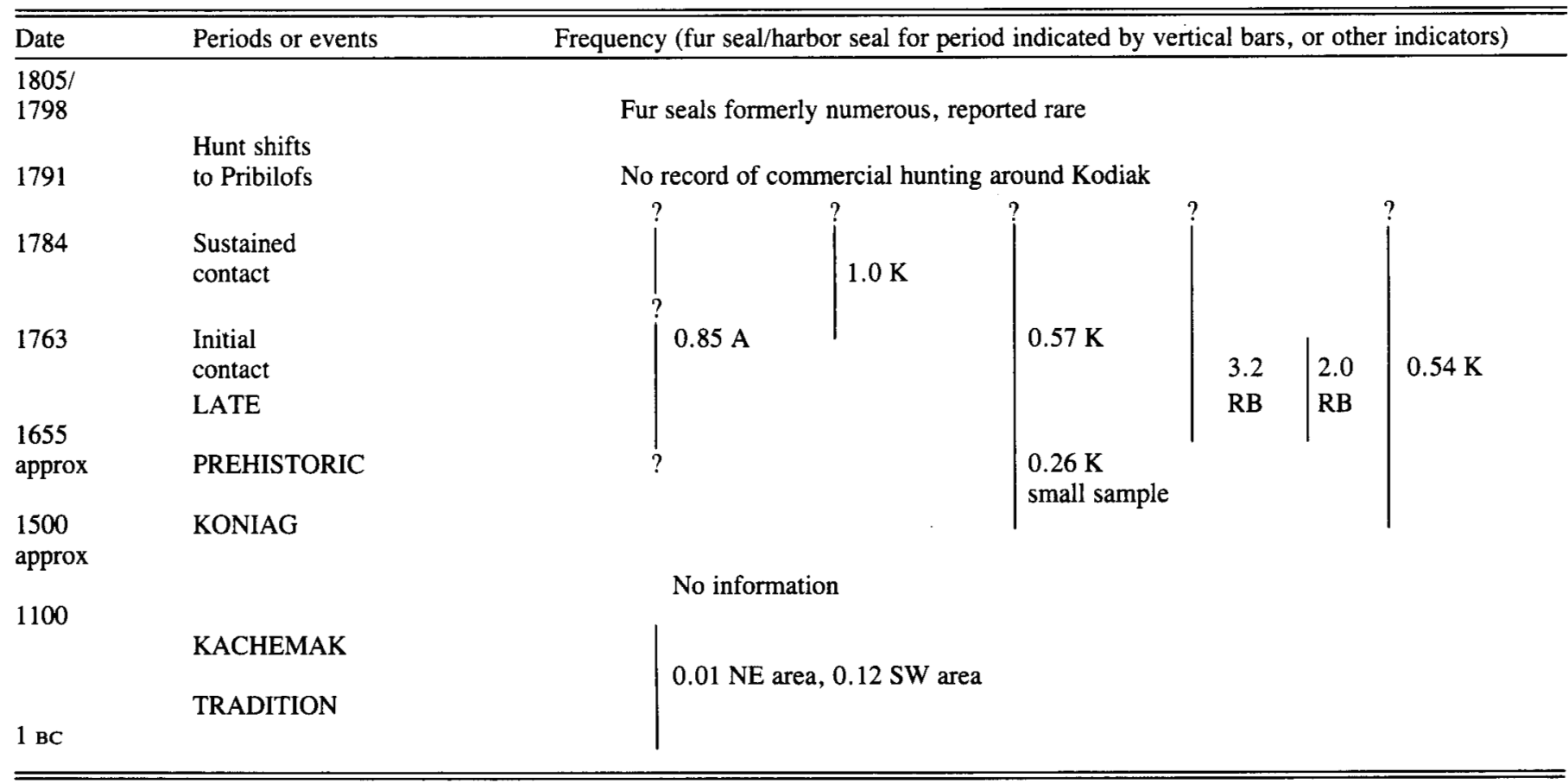

$\mathrm{A}=$ Artel site, $\mathrm{K}=\mathrm{Kiavak}$ stie, $\mathrm{RB}=$ Rolling Bay site

Saints site and progressing through three vertical subdivisions of the Kiavak site, the ratio of fur to harbor seal increases from the first millennium A.D. to the end of the 18 th century by the successive values $0.12,0.26,0.57$ and 1.0 . The trend at Rolling Bay is similar, though traced through fewer steps, but is more pronounced. Changes demonstrated to have occurred at single localities reduce the possibility of these particular differences being due to variations between hunting (e.g., sampling) localities; and if there was no change in the scheduling of hunting activity, differences in seasonality also can be eliminated as a variable. On the basis of data examined elsewhere (Clark, n.d.), the rise to a high incidence of fur seal bones appears to predate European contact by a very short interval - perhaps only a few decades. The evidence from one site suggests that fur seal utilization continued into the historic period.

\section{ETHNOGRAPHIC EVIDENCE}

Confirmation of this activity can be expected from early historical ethnographies, but this is not particularly the case. Among numerous reports and records examined, I have found only five references linking fur seals and the native Koniag inhabitants of Kodiak Island. The most definitive statement was recorded in 1790 by several members of the Billings expedition:

They begin their chase in February on the south side of Kadiak; the kotic [fur seal; seal or hair seal are referred to separately] continues all March; in April they depart from Kadiak to the neighboring islands for sea otters. . . . [Sauer, 1802:178.]

\section{HISTORICAL CONSIDERATIONS}

The dramatic rise in fur seal hunting on Kodiak began about 1650 A.D. (1700, according to a short dating option). One might suspect that the stimulus of the European and Asian fur market was behind this, but no reasonable amount of speculation can account for significant foreign contacts that early. However, the visibility of the evidence for early contact remains to be adequately documented by archaeologists. Initially, the Russians had limited goods for trading.

Although the activities of the Russian fur hunters and traders are not completely documented, little is to be gained by invoking the unknown. The facts are too well contained in legends and in records. Both native tradition (Bancroft, 1886:147) and written historic accounts essentially agree on the first Russian visit to Kodiak. Whether this was by Pan'kov in 1761 or Glotov in 1763 entails a difference of only two years. Russian hunters and traders only reached Umnak in 1753 , Unalaska probably by 1759 , and the western end of the Alaska Peninsula in 1761 (Berkh, 1974). This record of trading expeditions exists because of the administrative requirement for granting permission to sail and for the collection of taxes (cf. Makarova, 1975:108-109), though places visited are not always recorded. No firm evidence can be adduced for unrecorded earlier voyages to Kodiak or for an outside stimulus prompting a focus on hunting fur seals.

The quest of the sea otter is nearly synonymous with early Russian enterprise in the North Pacific. But another animal the northern fur seal - often was the mainstay of the Russian fur trade. Shelikhov, who later established a settlement on Kodiak, was so active in this trade as a shareholder that Bancroft (1886:185, footnote 23) remarks on his particular interest in this fur.

The Russians obtained furs by means of their own hunters, by enlisting (or forcing) the services of local natives as hunters, and by trade, initially from the Aleuts located west of Kodiak. Accustomed, thus, to obtaining fur seal pelts through native Alaskan hunters, as well as through their own efforts, the Russians undoubtedly would have continued this practice on 
Kodiak. Accordingly, one would expect a significant seal hide export from Kodiak up to the time the fur seal fishery was shifted to the Pribilof Islands. Fur shipment records do not bear this out.

The three confirmed voyages to Kodiak prior to 1784 could not induce the Koniags to trade furs. Details of the cargo of the Adrian i Nataliia, which sailed under Glotov, are not reported (Berkh, 1974:Table I). The Mikhail, under Polutov, returned with 1430 fur seal, but the account of the voyage suggests that these were gathered at places other than Kodiak. The Kliment, under Ocheredin, returned with only 61 fur seal among other furs, and these were not necessarily obtained from Kodiak.

Shelikhov came next, in 1784, and returned to Siberia in 1786 on the Trekh Sviatitelei (Shelikhov, 1981). His cargo was not large, though it included 266 fur seal, not necessarily killed on Kodiak. The next shipments from Kodiak, in 1789 and 1792 , did not include any fur seal pelts (Berkh, 1974:Table II). This period is followed by a massive influx of furs from the Pribilof Islands.

From this review of fur shipments, there is no indication of any more than possibly 266 fur seal hides having been shipped from Kodiak. Although staff of the Billings expedition in 1790 reported that the late winter fur seal hunt was part of the native annual cycle (quoted earlier), no fur seal are reported in the cargo of the Mikhail, which in 1792 carried the first shipment from Kodiak after the visit of the Billings expedition. There is no evident reason why this should be the case. In 1790 the Shelikhov-Golikov Company at Kodiak had yet to send a ship to the Pribilof Islands (Shelikhov correspondence to Delarov in Pierce and Donnelly, 1979:19-20). Sauer and others of the Billings expedition possibly were describing past activity at Kodiak that had been reported to them by a company employee.

\section{BIOLOGICAL CONSIDERATIONS AND CONCLUSIONS}

Maritime hunting culture patterns are notable for their persistence The late-prehistoric or protohistoric rise in the fur seal fishery on southeastern Kodiak is unlikely to have been brought about by the whim of the Koniags, by new technology, or by a discovery that for six millennia a readily available resource had been overlooked. We can speculate, though, that a resource formerly only sporadically encountered within an economical harvesting range had become more accessible. For example, changes in storm patterns may have resulted in seal herds being forced close to shore, as is known to occur in the Aleutian Islands (Merck, 1980:88). Farther south, several thousand female fur seal regularly enter deeper inlets along the west coast near Sitka to feed on spawning herring during the winter (Kenyon and Wilke, 1953:P1. II). Sitkalidak Strait, and especially Three Saints Bay, once was noted for its prime large herring. Herring possibly attracted fur seals into this area; but to explain changes in fur seal distribution, there also would have to have been fluctuations in the herring distribution.

Although extensive Koniag utilization of fur seals is sufficiently late that it is necessary to carefully weigh the evidence for it having occurred during fully prehistoric times, predicted behavior of the Russian fur hunters, who would have encouraged and capitalized on the Koniag fur hunt, failed to materialize. Later, in 1798, Baranov wrote that there "is no fur seal hunting here"' (around Kodiak and eastward to Yakutat Bay) (Pierce and Donnelly, 1979:item 24). It appears from the context that Baranov meant there were no fur seals to be hunted. In 1805 Lisianski wrote that "sea bears [fur seals] also were formerly tolerably numerous, but are now very seldom seen" around Kodiak (1814:192 — emphasis added).

Fur seal, always occasionally present in the area, evidently had become more accessible from some time before 1650 into the late $1780 \mathrm{~s}$. Then they again ceased to become commonplace in nearshore areas. Archaeological evidence shows that in the case of presumably stable maritime ecosystems the past may not always be assumed from the present.

\section{ACKNOWLEDGEMENTS}

In writing this article I have benefitted from the detailed historical knowledge and critical reading of Dr. Lydia Black. Pat Sutherland helped with references to publications noting west coast fur seal occurrences and with unpublished archaeological data. Preparation of this paper has been supported by the National Museum of Man, Ottawa.

The basic data used here were published two decades ago; however, later publication of documents from Russian archives and translations of historical works have facilitated further analysis, which it would have been very difficult to do previously.

\section{REFERENCES}

BANCROFT, H.H. 1886. History of Alaska 1730-1885. San Francisco: The History Co. (1959 reprint, New York: Antiquarian Press.) 775 p.

BANFIELD, A.W.F. 1974. The Mammals of Canada. Toronto: University of Toronto Press. 438 p.

BERKH, V.N. (KRENOV, D., trans.; PIERCE, R.A., ed.) 1974. A Chronological History of the Discovery of the Aleutian Islands or the Exploits of Russian Merchants. Kingston: Limestone Press. 127 p.

CLARK, D.W. 1970. The late Kachemak tradition at Three Saints and Crag Point, Kodiak Island, Alaska. Arctic Anthropology 6(2):73-111. 1974. Koniag Prehistory. Tubinger Monographien zur Urgeschichte. Vol. 1. Verlag W. Kohlhammer. 271 p.

n.d. (1984) The Kodiak Island fur seal hunt: ecological mystery and unrecorded history in Alaska. Typescript on file, Records Section, Archaeological Survey of Canada, National Museum of Man, Ottawa.

GUSTAFSON, C.E. 1968. Prehistoric use of fur seals: evidence from the Olympic coast of Washington. Science 161:49-51

KENYON, K.W., and WILKE, F. 1953. Migration of the Northern Fur seal, Callorhinus ursinus. Journal of Mammology 34(1):86-98.

LIPPOLD, L.K. 1966. Chaluka: the economic base. Arctic Anthropology 3(2):125-131.

LISIANSKI, Y. 1814. A Voyage Round the World in the Years 1803, 4, 5, \& 6 London: John Booth. 388 p.

MAKAROVA, R.V. (PIERCE, R.A., and DONNELLY, A.S., trans. and eds.) 1975. Russians on the Pacific $-1748-1799$. Kingston: Limestone Press. $388 \mathrm{p}$.

MERCK, C.H. (JAENSCH, F., trans,; PIERCE, R.A., ed.) 1980. Siberia and Northwest America, 1788-1792: The Journal of Carl Heinrich Merck, Naturalist with the Russian scientific expedition led by Captains Joseph Billings and Gavril Sarychev. Kingston: Limestone Press. 216 p.

PIERCE, R.A., and DONNELLY, A.S., eds. (KRENOV, D., trans.) 1979. A History of the Russian American Company. Vol. 2: Documents. Kingston: Limestone Press. 257 p.

PIKE, C.G., and MACASKIE, I.B. 1969. Marine Mammals of British Columbia. Ottawa: Research Fisheries Board of Canada Bulletin No. 171.

SAUER, M. 1802. An Account of a Geographical and Astronomical Expedition to the Northern Parts of Russia. London: Cadell and Davies. 332 p.

SHELIKHOV, G.I. (RAMSAY, M., trans.; PIERCE, R.A., ed.) 1981. A Voyage to America 1783-1786. Kingston: Limestone Press. 162 p. 